\title{
Evaluation of enzyme inhibitory and antioxidant activity of some Lamiaceae plants
}

\author{
Hasya Nazlı EKİN ${ }^{1}$ * (D), Didem DELIORMAN ORHAN ${ }^{1}$ (D), İlkay ERDOĞAN ORHAN ${ }^{1}$ (D), \\ Nilüfer ORHAN 1 (D), Mustafa ASLAN 1 (D) \\ 1 Department of Pharmacognosy, Faculty of Pharmacy, Gazi University, Yenimahalle 06330, Ankara, Turkey, \\ * Corresponding Author. E-mail: hasyaekin@gmail.com (H.N.E.); Tel.+90-312-202 3172.
}

Received: 28 November 2018 / Revised: 09 April 2019 / Accepted: 13 April 2019

\begin{abstract}
Lamiaceae is one of the most widespread families in Turkey. The aim of this study was to determine antialzheimer, antidiabetic, antioxidant and antiobesity activities of ethanol extracts of Lamium purpureum var. purpureum, Origanum onites, Salvia sclarea, S. virgata and Thymus zygioides var. lycaonius. Acetylcholinesterase, butyrylcholinesterase, a-amylase, a-glucosidase, and pancreatic lipase inhibitory activities were tested for the determination of the activity of these extracts. Furthermore, total antioxidant, ferric-reducing antioxidant power, metalchelating and $N, N$-dimethyl- $p$-phenylendiamine radical scavenging assays were utilized to screen antioxidant activity. Total phenolic content of the extracts were also calculated. Among the tested extracts, T. zygioides var. lycaonius aerial part extract $(85.28 \pm 0.89 \%)$ showed the highest inhibitory activity against a-glucosidase. The inhibitory activities of all extracts against a-amylase were lower than $50 \%$. S. sclarea leaf extract indicated remarkable butyrylcholinesterase inhibition $(51.76 \pm 1.04 \%)$, but all of the plant extracts were inactive against acetylcholinesterase. The Salvia species showed the highest total antioxidant activity. S. sclarea flower $(1.34 \pm 0.08)$ and leaf $(1.34 \pm 0.08)$ extracts showed the highest ferric-reducing antioxidant power activities. Our findings indicated that O. onites, S. sclarea, S. virgata, and T. zygioides var. lycaonius extracts showed valuable inhibitory activity and emerged as the sources of possible a-glucosidase inhibitors for future studies.
\end{abstract}

KEYWORDS: Lamiaceae; anticholinesterase; antidiabetic; antiobesity; antioxidant.

\section{INTRODUCTION}

Diabetes mellitus (DM) is a metabolic disorder caused by impairments in insulin action or secretion. Hyperglycemia, which is constantly present in diabetes patients, causes various chronic disorders such as nephropathy, neuropathy, and retinopathy [1]. It has been indicated that the high blood sugar also causes increased free radicals and decreased antioxidant markers [2]. Free radicals and intracellular antioxidant mechanisms play essential roles in DM and pathogenesis of Alzheimer's disease (AD).

Reduction of absorption of carbohydrates is one of the approaches in the treatment of DM. Thus, the postprandial rise of blood sugar is reduced. Inhibition of a-amylase and a-glucosidase enzymes, involved in the digestion of oligosaccharides and polysaccharides, can reduce increase of glucose in the blood significantly [3]. These two enzyme systems are widely used in vitro antidiabetic activity screening studies.

Obesity is a metabolic disorder, which is characterized by excess fat accumulation. It is demonstrated that obesity may cause many of chronic diseases such as dementia, type $2 \mathrm{DM}$, hypertension, dyslipidemia and depression [4]. The most important target of treatment of obesity is inhibition of food digestion and absorption to the blood. Inhibition of pancreatic lipase and lipid absorption is a very effective approach to find effective drugs for the treatment of obesity. Many plants, bacteria, fungi and marine organisms have been screened to find new compounds that are inhibiting pancreatic lipase for the treatment of obesity [5].

Pancreatic lipase inhibition is the most commonly used enzymatic method in obesity researches. Triglycerides are digested to fatty acids by the action of pancreatic lipase. When pancreatic lipase is inhibited, dietary fats cannot be absorbed into blood [6]. This way, people who consume fatty foods may be prevented from gaining weight. According to the results of our pancreatic lipase inhibitory activity, it was revealed that the plants tested are not effective in obesity control due to their low capacity to inhibit pancreatic lipase.

How to cite this article: Ekin HN, Deliorman Orhan D, Erdoğan Orhan I, Orhan N, Aslan M. Evaluation of enzyme inhibitory and antioxidant activity of some Lamiaceae plants. J Res Pharm. 2019; 23(4): 749-758. 
It is well known that cognitive dysfunction and dementia are important complications of DM and obesity that reduce quality of life $[7,8]$. The sister enzymes; acetylcholinesterase (AChE) and butyrylcholinesterase $(\mathrm{BChE})$ are associated with the formation of dementia types, $\mathrm{AD}$ in particular. Therefore, cholinesterase inhibitors are currently the most used drug class in the treatment of AD. Although inhibition of both enzymes contributes to $\mathrm{AD}$ treatment, recent studies have reported that $\mathrm{BChE}$ inhibition will also lead to more effective treatment [9].

Lamiaceae is one of the most widespread families that contains 45 genera and 550 species in Turkey. It is rich in plants with several biological activities and many species of the family are utilized traditionally for various diseases [10]. The infusions of Origanum onites (kekik) and Thymus zygioides var. lycaonicus (kekik, kır çayı, taş kekiği) are used traditionally in treatment of DM [11-13]. It has been indicated that the species of Salvia have been used against dementia in Europe [14]. On the other hand, many researchers have conducted studies on the antidiabetic activities of Salvia and Lamium species to date [15,16]. Also, literature survey clearly demonstrated that there are many studies on anticholinesterase activity of different Origanum, Salvia, and Thymus species [17-19].

Because of these reasons, the present study assessed the in vitro antioxidant, anticholinesterase, antiobesity and antidiabetic potentials of five Lamiaceae plants (Lamium purpureum var. purpureum L., Origanum onites L., Salvia sclarea L., S. virgata Jacq., Thymus zygioides Griseb. var. lycaonicus (Celak.) Ronniger) by using different biochemical enzyme and chemical reagent assays. Additionally, total phenolic contents of these plants were determined using the Folin Ciocalteu method.

\section{RESULTS}

In this study, the ethanol extracts of the aerial parts of L. purpureum var. purpureum, O. onites, S. virgata, T. zygioides var. lycaonius, and leaves and flowers of S. sclarea were screened against a-amylase and aglucosidase, $\mathrm{AChE}, \mathrm{BChE}$ and pancreatic lipase enzymes. Antioxidant activity of the extracts was also determined by total antioxidant activity by phosphomolybdenum assay, ferric-reducing antioxidant power (FRAP), ferric ion-chelating and DMPD ( $N, N$-dimethyl- $p$-phenylendiamine) radical scavenging activities. All enzyme inhibitory activities and antioxidant assays were tested at initial concentrations of $2000 \mu \mathrm{g} / \mathrm{ml}$. The activities of the extracts on the a-glucosidase enzyme were also studied at lower concentrations and $\mathrm{IC}_{50}$ values were determined, because most of extracts was showed the a-glucosidase inhibitory activity higher than $50 \%$ at $2000 \mu \mathrm{g} / \mathrm{ml}$. Detailed information about the results of activities was given in Tables 2-4.

Total phenol contents of the extracts were measured using Folin Ciocalteu method and expressed as Gallic acid equivalents (GAE). According to our results, total phenol contents of the extracts varied from 90.05 \pm 3.73 to $193.67 \pm 7.89 \mathrm{mg} \mathrm{GAE} / \mathrm{g}$ extract (Table 1). Consequently, there seems to be no correlation between the total phenol content of extracts and enzyme inhibitory and antioxidant activity except DMPD radical scavenging activity.

Table 1. Yield percentages $(\mathrm{w} / \mathrm{w})$, total phenolic contents (mg GAE/g extract) of the extracts and parts of the plants.

\begin{tabular}{llcc}
\hline Plant & Part used & $\begin{array}{c}\text { Yield } \\
(\mathbf{w} / \mathbf{w})\end{array}$ & $\begin{array}{c}\text { Total Phenolic Content } \\
\text { (mg/g) GAE } \pm \text { SEM }\end{array}$ \\
\hline Lamium purpureum var. purpureum & Aerial part & 20.27 & $93.50 \pm 1.44$ \\
Origanum onites & Aerial part & 22.96 & $112.37 \pm 8.02$ \\
Salvia sclarea & Leaf & 19.15 & $123.06 \pm 21.15$ \\
Salvia sclarea & Flower & 28.51 & $90.05 \pm 3.73$ \\
Salvia virgate & Aerial part & 15.04 & $193.67 \pm 7.89$ \\
Thymus zygioides var. lycaonicus & Aerial part & 10.53 & $193.47 \pm 4.45$ \\
\hline
\end{tabular}

GAE: Gallic acid equivalent a Standard error of the mean $(n=3)$

a-Glucosidase inhibitory activity results showed that the extract of T. zygioides var. lycaonicus was found to have the highest inhibitory activity with $546.7 \mu \mathrm{g} / \mathrm{ml} \mathrm{IC} C_{50}$ value among all tested plant extracts (Table 3). $\alpha$ Glucosidase inhibitory activities of the other extracts followed the order: O. onites $>$ S. sclarea (leaf) $>$ S. sclarea (flower) $>$ S. virgata $>$ L. purpureum var. purpureum. Acarbose used as reference exerted strong a-glucosidase inhibitory activity with $\mathrm{IC}_{50}$ value of $181.4 \mu \mathrm{g} / \mathrm{ml}$ (Table 3). On the other hand, a-amylase inhibitory activity 
of all tested extracts was found to be extremely weak $(2.30 \pm 0.21-8.93 \pm 1.73 \%)$. L. purpureum var. purpureum extract was found to be inactive at tested concentration.

Except for L. purpureum var. purpureum, S. virgata and T. zygioides var. lycaonicus extracts, the rest of the extracts showed moderate activities $(20.72 \pm 2.08-24.34 \pm 1.90 \%)$ on pancreatic lipase. In this study, orlistat that is used for the management of obesity inhibited pancreatic lipase enzyme with $64.53 \pm 0.32 \%$ at $1 \mu \mathrm{g} / \mathrm{ml}$ (Table 2).

Table 2. Inhibitory activity of the extracts against a-glucosidase, a-amylase, pancreatic lipase, AChE and BChE enzymes at $2000 \mu \mathrm{g} / \mathrm{ml}$ concentration

\begin{tabular}{|c|c|c|c|c|c|}
\hline \multirow[b]{2}{*}{ Plant } & \multicolumn{5}{|c|}{ Inhibitory activity $\left(\% \pm \mathrm{SEM}^{\mathrm{a}}\right)$} \\
\hline & a-Glucosidase & a-Amylase & $\begin{array}{c}\text { Pancreatic } \\
\text { lipase }\end{array}$ & AChE & BChE \\
\hline L. purpureum var. purpureum & $46.75 \pm 1.54^{* * *}$ & - & - & - & $8.52 \pm 0.61^{* * *}$ \\
\hline O. onites & $77.39 \pm 0.76^{* * *}$ & $3.16 \pm 0.99 \mathrm{~ns}$ & $20.72 \pm 2.08^{*}$ & - & $15.56 \pm 1.69^{* * *}$ \\
\hline S. sclarea (Leaves) & $72.95 \pm 1.04^{* * *}$ & $2.30 \pm 0.21 \mathrm{~ns}$ & $24.23 \pm 0.18^{* *}$ & - & $51.76 \pm 1.04^{* \star *}$ \\
\hline S. sclarea (Flowers) & $64.72 \pm 1.06^{* * *}$ & $8.07 \pm 0.15^{\star}$ & $24.34 \pm 1.90^{\star *}$ & - & $31.91 \pm 1.01^{\star \star \star}$ \\
\hline S. virgata & $61.15 \pm 2.03^{* * *}$ & $8.93 \pm 0.10^{* *}$ & - & - & - \\
\hline T. zygioides var. lycaonicus & $85.28 \pm 0.89^{* \star *}$ & $8.93 \pm 1.73 \mathrm{~ns}$ & - & - & $30.92 \pm 1.44^{\star * \star}$ \\
\hline Reference & $85.30 \pm 0.46^{b^{* * *}}$ & $91.00 \pm 0.43^{b^{* * *}}$ & $64.53 \pm 0.32^{c^{* * *}}$ & $95.50 \pm 1.31^{\mathrm{d}^{\star * *}}$ & $87.51 \pm 0.24 \mathrm{~d}^{* * *}$ \\
\hline
\end{tabular}

The inhibitory activity results of the extracts on cholinesterase enzymes displayed that the extracts had no AChE inhibitor activity. Conversely, the highest BChE inhibitor activity was seen in S. sclarea leaf extract with $51.76 \%$ value. S. sclarea flower and T. zygioides var. lycaonicus extracts also showed moderate BChE inhibitor activities (31.91\%). Only S. virgata extract was found to be inactive against BChE enzyme. In this assay, galantamine used as reference inhibited BChE with $87.51 \pm 0.24 \%$ at $1 \mathrm{mg} / \mathrm{ml}$ (Table 2).

Table 3. The $\mathrm{IC}_{50}$ value of a-glucosidase inhibitory activity of the extracts.

\begin{tabular}{lc}
\hline \multicolumn{1}{c}{ Plant } & IC $_{50}(\mu \mathrm{g} / \mathrm{mL} \pm$ SEM $)$ \\
\hline L. purpureum var. purpureum & $>2000$ \\
O. onites & $814.00 \pm 5.02$ \\
S. sclarea (Leaves) & $877.87 \pm 15.34$ \\
S. sclarea (Flowers) & $1075.00 \pm 44.51$ \\
S. virgata & $1113.67 \pm 36.91$ \\
T. zygioides var. lycaonicus & $565.20 \pm 7.92$ \\
\hline Acarbose & $0.33 \pm 0.03$ \\
\hline a Standard error of the mean $(\mathrm{n}=3)$ &
\end{tabular}

Total antioxidant activity determined by phosphomolybdenum assay and expressed as ascorbic acid equivalents (AAE). The Salvia species showed the highest total antioxidant activity $(209.72 \pm 2.35-490.20 \pm$ 1.16 AAE). FRAP assay is one of the methods used to evaluate the antioxidant activity. The extracts (1.12 \pm $0.08-1.17 \pm 0.06$ ) were found to have better antioxidant effects compared to reference compound quercetin $(0.97 \pm 0.10)$. In the DMPD radical scavenging assay, ascorbic acid $(69.46 \pm 2.14 \%)$ showed a potent activity while the extracts showed little or no activity. Except for L. purpureum var. purpureum (18.42 $\pm 1.17 \%$ ), all extracts were inactive on ferric-ion chelating activity assay (Table 4). 
Table 4. Ferric reducing antioxidant power (FRAP), ferric ion-chelating and DMPD radical scavenging activity.

\begin{tabular}{|c|c|c|c|c|}
\hline Plant & $\begin{array}{c}\text { Total } \\
\text { antioxidant } \\
\left(\mathrm{AAE} \pm \mathrm{SEM}^{\mathrm{b}}\right)\end{array}$ & $\begin{array}{c}\text { FRAPa } \\
\text { (Abs. at } 700 \mathrm{~nm} \pm \\
\text { SEM }^{\mathrm{b}} \text { ) }\end{array}$ & $\begin{array}{l}\text { Ferric ion-chelating act. } \\
\qquad\left(\% \pm S E M^{b}\right)\end{array}$ & $\begin{array}{c}\text { DMPD } \\
\text { scavenging } \\
\left(\% \pm \text { SEM }^{\mathrm{b}}\right)\end{array}$ \\
\hline $\begin{array}{l}\text { L. purpureum var. } \\
\text { purpureum }\end{array}$ & $58.21 \pm 0.85$ & $1.17 \pm 0.06^{* * *}$ & $18.42 \pm 1.17 \mathrm{~ns}$ & - \\
\hline O. onites & $44.82 \pm 1.10$ & $1.12 \pm 0.08^{* \star *}$ & - & $20.53 \pm 0.04^{* *}$ \\
\hline S. sclarea (Leaves) & $490.20 \pm 1.16$ & $1.34 \pm 0.08^{* * *}$ & - & $20.60 \pm 8.69^{* *}$ \\
\hline S. sclarea (Flowers) & $209.72 \pm 2.35$ & $1.34 \pm 0.08^{* * *}$ & - & $7.87 \pm 1.76^{\mathrm{ns}}$ \\
\hline S. virgata & $225.23 \pm 0.68$ & $1.27 \pm 0.01^{* \star *}$ & - & $30.12 \pm 1.29^{* *}$ \\
\hline $\begin{array}{l}\text { T. zygioides var. } \\
\text { lycaonicus }\end{array}$ & $17.34 \pm 1.06$ & $1.29 \pm 0.08^{* \star *}$ & - & $22.57 \pm 0.73^{* *}$ \\
\hline Reference & & $0.97 \pm 0.10^{\mathrm{c}^{* * *}}$ & $94.98 \pm 0.06^{d}$ & $69.46 \pm 2.14 \mathrm{e}^{\star \star \star}$ \\
\hline
\end{tabular}

a Higher absorbance indicates greater antioxidant activity, ${ }^{b}$ Standard error of the mean $(\mathrm{n}=3)$, c Quercetin $1000 \mu \mathrm{g} / \mathrm{ml}$,

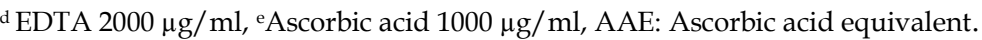

\section{DISCUSSION}

Medicinal plants are extremely good resources for finding new drug molecules for the treatment of DM and Alzheimer's disease. In this report, we tried to evaluate antioxidant, antidiabetic, anticholinesterase, and antiobesity activities of five Lamiaceae plants. The results of the in vitro activity tests have shown that detailed studies are needed on some of the tested species.

The a-glucosidase inhibitory activity results have been supported the traditional use of $O$. onites and $T$. zygioides var. lycaonicus in DM treatment. In previous studies, it is demonstrated that O. majorana, O. vulgare ssp. hirtum, T. satureioides, T. praecox subsp. skorpilii var. skorpilii and T. vulgaris also exhibited antidiabetic activity in experimental diabetic rats and T. capitatus showed a-amylase inhibitory activity [16, 20-24].

According to the results of an in vivo antidiabetic study, it was thought that Salvianolic acid B is the major bioactive compound in S. miltiorrhiza [25]. The antidiabetic activities of S. officinalis, S. fruticosa, S. lavandulifolia, S. triloba and S. hispanica were also exhibited [16, 26-30]. With bioactivity guided isolation technique, the a-amylase inhibitory activity of $S$. virgata was attributed to chrysoeriol by Nickavar and Abolhasani [31]. As a result of bioassay guided isolation studies to date, different structured compounds (5hydroxy-7,4'-dimethoxyflavone, amarisolide, pedalitin, apigenin-7-O- $\beta$-D-glucoside, the flavone 2-(3,4dimethoxyphenyl)-5,6-dihydroxy-7-methoxy-4H-chromen-4-one, luteolin-7-O-glucoside, luteolin-7-Oglucuronide, diosmetin-7-O-glucuronide, $(1 R, 5 S, 7 S, 8 S, 9 R, 10 R, 12 R)-1,7,8$-trihydroxycleroda-3,13(16),14triene-17,12;18,19-diolide, and oleanolic acid) exhibiting a-glucosidase inhibitory activity were isolated from Salvia species [32-35]. Since many Salvia species (S. triloba, miltiorrhiza, hydrangea, officinalis etc.) have been found to have in vitro and in vivo antidiabetic activity, S. virgata and S. sclarea extracts taken into this study and have been consistently found to have strong a-glucosidase enzyme inhibitory activity.

On the other hand, S. miltiorrhiza also exerted protective activity against memory and learning impairments in streptozotocin-induced diabetic rats [36-38]. Likewise, the protective effects of S. officinalis against memory and learning deficiency induced by diabetes was shown and this activity was attributed to rosmarinic acid [39].

On the other hand Şenol et al. [17] studied AChE inhibitory activity of 55 different taxa of Salvia. Among the tested extracts, only $S$. fruticosa showed relatively significant AChE inhibitory activity. In these study at 25, 50 and $100 \mu \mathrm{g} / \mathrm{ml}$ of the ethyl acetate and dichloromethane extracts of S. virgata, which was collected from Ankara, Turkey and it has been observed that the extract does not have any enzyme inhibitory effect compared with galanthamine $(98.97 \pm 0.24 \%$ at $100 \mu \mathrm{g} / \mathrm{ml})$. In our study, among the Salvia species tested, it was also found that $S$. virgata ethanolic extract, which was collected from Isparta, Turkey did not show any inhibitory activity on both $\mathrm{AChE}$ and $\mathrm{BChE}$ enzymes, whereas the leaf ethanol extract of S. sclarea had strong BChE inhibitory activity. In another study, which was conducted by Kindl et al., T. longicaulis, $T$. 
praecox subsp. polytrichus, T. pulegioides, T. serpyllum subsp. serpyllum, T. striatus, and T. vulgaris were demonstrated inhibitory activity against AChE [18]. This activity may be caused from carvacrol, which is one of most important compounds of Thymus species [40]. On the other hand, it was displayed that Origanum majorana has strong AChE activity and the active compound of O. majorana was found as ursolic acid [19]. As Topçu et al. [41] emphasized, the Lamiaceae is family rich in species with potent anticholinesterase activity.

This literature data support that there is no relationship between the total phenol content of our tested extracts and their anticholinesterase inhibitory activity.

Oxidative stress plays an important role in the pathogenesis of many neurodegenerative diseases and DM. Therefore, the plant extracts having antidiabetic or anticholinesterase activity are also expected to show antioxidant activity. The Salvia species (S. sclarea, and S. virgata) exhibited more total antioxidant activity when compared to the other extracts. In this investigation, among the tested antioxidant activities, we have noticed that all extracts have strong FRAP activities. The reducing properties of the test samples were measured by this method. These samples having reduction potential donate an electron to free radicals and convert them into more stable forms. And thus, free radicals that convert to this stable form can be prevented from causing membrane lipid peroxidation. This mechanism prevents the deterioration of cell membrane stability caused by excess free radicals occurring in Alzheimer and DM.

Although T. zygioides var. lycaonicus was used traditionally against diabetes, no previous studies of antidiabetic and antialzheimer activities of T. zygioides var. lycaonicus have been found. This is the first study on enzyme inhibitory effects of $T$. zygioides var. lycaonicus. The activity of $O$. onites essential oils was indicated against cholinesterase enzymes by Orhan et al. [42], but the inhibitory activity of aerial part of $O$. onites and $L$. purpureum var. purpureum against a-amylase, a-glucosidase, pancreatic lipase, and cholinesterase enzymes was demonstrated in this study for the first time.

\section{CONCLUSION}

The results of the study indicated that except for L. purpureum var. purpureum, all tested plants herein belonging to Lamiaceae family have shown inhibitory effects against the a-glucosidase. Significant activity against pancreatic lipase was observed only with $S$. sclarea and O. onites extracts. In addition, the fact that all the extracts tested had strong FRAP activities suggest that they would provide significant protection against oxidative stress in DM and AD. Further studies should be focused on the BChE inhibitory activity of S. sclarea flower and T. zygioides var. lycaonicus aerial part extract and $\alpha$-glucosidase inhibitory activity of T. zygioides var. lycaonicus.

\section{MATERIALS and METHODS}

\subsection{Plant materials}

The aerial parts of Lamium purpureum var. purpureum, Origanum onites were collected in May 2015, the herbs of Salvia virgata, Thymus zygioides var. lycaonicus, leaves and flowers of S. sclarea were collected in June 2014 from Isparta Turkey. The plants were identified by Dr. Ufuk ÖZBEK (Gazi University, Faculty of Science and Arts, Department of Biology, Ankara) and Dr. Galip AKAYDIN (Hacettepe University, Faculty of Science and Arts, Department of Biology, Ankara). Herbarium specimens are stored in the Herbarium of Faculty of Pharmacy Gazi University, Ankara, Turkey (GUEF 3439, GUEF 3445, GUEF 3431, GUEF 3447, GUEF 3429, respectively).

\subsection{Extraction}

The dried and powdered plant materials (10 g) were extracted with ethanol $(80 \%, 200 \mathrm{ml})$ on a shaker. After filtration, the extracts were concentrated under vacuum $\left(\right.$ at $40^{\circ} \mathrm{C}$ ) by evaporation to dryness. The extraction was repeated for three times and the dried extracts were pooled. The yields of the extracts are given in Table 1. For the determination of enzyme inhibitory activities, in order not to affect enzyme activities, the extracts were dissolved in DMSO (3\%), and for antioxidant activities was dissolved in ethanol $(80 \%)$.

\subsection{Enzyme inhibitory activities}

\subsubsection{Cholinesterase inhibitory activity}

$\mathrm{AChE}$ and BChE inhibitory activities of the extracts were measured by slightly modifying the spectrophotometric method developed by Ellman et al. [43]. Horse serum BChE (EC 3.1.1.8, Sigma, St. Louis, MO, USA) and electric eel AChE (Type-VI-S; EC 3.1.1.7, Sigma, St. Louis, MO, USA) enzymes were used as 
enzyme sources. Butyrylthiocholine chloride (BChC) and acetylthiocholine iodide (AChI) (Sigma, St. Louis, MO, USA) were used as substrates. First of all, $20 \mu \mathrm{l}$ of test solution, Ellman's reagent, and enzyme solution were added in sodium phosphate buffer $(\mathrm{pH} 8.0)$ and incubated for $15 \mathrm{~min}$ at $25^{\circ} \mathrm{C}$. The reaction was started with the addition of substrate and the substrate was hydrolyzed to thiocholines. As a result of the reaction of thiocholines with Ellman's reagent yellow colored 5-thio 2-nitrobenzoate anion occurs. Change in absorbance (at $412 \mathrm{~nm}$ ), utilizing a 96-well microplate reader (VersaMax Molecular Devices, Sunnyvale, CA, USA). Percentage inhibition of the enzymes was determined by using the formula: Inhibition $(\%)=(B-S) / B \times 100$ where $B$ is the activity of the enzyme without test sample and $S$ is the activity of the enzyme with a test sample. The experiments were done in triplicate. Galanthamine (Sigma, St. Louis, MO, USA) was used as the reference.

\subsection{2. a-Amylase inhibitory activity}

The a-amylase inhibition method was performed according to the method by Ali et al. [44] with slight modification. For the preparation of enzyme solution, porcine pancreatic a-amylase (EC 3.2.1.1, type VI, Sigma) was dissolved in ice-cold distilled water $(4 \mathrm{U} / \mathrm{ml})$. Potato starch $(0.5 \%, \mathrm{w} / \mathrm{v})$ in $20 \mathrm{mM}$ phosphate buffer ( $\mathrm{pH}$ 6.9) was used as substrate solution. Plant extract and enzyme solution were mixed in an Eppendorf tube. The tubes were incubated at $37^{\circ} \mathrm{C}$ for $5 \mathrm{~min}$. Then the starch solution was added and the reaction was started. Then DNS color reagent solution (5.31 M sodium potassium tartrate in $2 \mathrm{M} \mathrm{NaOH}$ and $96 \mathrm{mM} 3,5-$ dinitrosalicylic acid) was added and heated at $85^{\circ} \mathrm{C}$. Tubes were cooled immediately and the absorbance of the mixture was read at $540 \mathrm{~nm}$. Acarbose was used as a reference. Experiments were performed with three replicates. The absorbance (A) according to the produced maltose is calculated with the following equation (Eq. 1):

$$
\mathrm{A}_{\text {control or plant extract }}=\mathrm{A}_{\text {Sample }}-\mathrm{A}_{\text {Blank }}
$$

The amount of produced maltose was determined by the calibration curve of maltose standard. Inhibition percentage was determined as: Inhibition $\%=$ (mean maltose in control-mean maltose in sample)/mean maltose in control $\times 100$.

\subsection{3. a-Glucosidase inhibitory activity}

a-Glucosidase inhibitory activity was carried out in accordance with the method of Lam et al. [45]. Enzyme solution of a-glucosidase type IV (Sigma Co., St. Louis, USA) from B. stearothermophilus was prepared with dissolving the enzyme in phosphate buffer ( $\mathrm{pH}$ 6.5). Extracts were preincubated with enzyme solution for $15 \mathrm{~min}$ at $37^{\circ} \mathrm{C}$. 4-Nitrophenyl $\beta$-D-glucopyranoside (Sigma) as substrate $(20 \mathrm{mM})$ was added and the incubation proceeded for $35 \mathrm{~min}$ at $37^{\circ} \mathrm{C}$. The substrate hydrolyzed with the enzyme to $p$-nitrophenol (yellow) and the resulting absorbance was measured with an Elisa plate reader (Versamax Tunable Microplate Reader) at a wavelength of $405 \mathrm{~nm}$. Acarbose (Bayer) was used as reference. The inhibition percentage (\%) was calculated according to this formula: Inhibition $(\%)=(B-S) / B \times 100$ where B is the activity of the enzyme without test sample and $S$ is the activity of the enzyme with a test sample.

\subsubsection{Pancreatic lipase inhibitory activity}

The inhibitory activities of the plant extracts on pancreatic lipase were determined by the method used by Lee et al. [46]. For the preparation of enzyme solution, porcine pancreatic lipase enzyme type II (Sigma) dissolved in a buffer (pH 6.8) contains $10 \mathrm{mM}$ MOPS (4-Morpholinepropanesulfonic acid, Sigma) and $1 \mathrm{mM}$ EDTA. Enzyme solution and extracts were mixed in Tris buffer $\left(100 \mathrm{mM}\right.$ Tris- $\mathrm{HCl}$ and $\left.5 \mathrm{mM} \mathrm{CaCl}_{2}, \mathrm{pH} 7.0\right)$ and preincubated for $15 \mathrm{~min}$ at $37^{\circ} \mathrm{C}$. Then substrate solution $(5 \mathrm{mM} \mathrm{p}$-nitrophenyl butyrate in dimethyl formamide) was added and proceed for $30 \mathrm{~min}$ at $37^{\circ} \mathrm{C}$. Lipase activity was determined by reading the absorbance generated by $p$-nitrophenol hydrolysis to $p$-nitrophenyl butyrate with an ELISA reader (Versamax Tunable Microplate Reader) at $405 \mathrm{~nm}$. Orlistat (Roche) was used as reference. Lipase inhibition (\%) was determined according to this formula: Inhibition $(\%)=(B-S) / B \times 100$ where B is the activity of the enzyme without test sample and $S$ is the activity of the enzyme with a test sample.

\subsection{Antioxidant activity assays}

\subsubsection{Total antioxidant activity by phosphomolybdenum assay}

Total antioxidant activity was conducted by Prieto et al. [47]. In the assay, Mo (VI) reduced to Mo (V) by the extracts and then the green phosphate/Mo $(\mathrm{V})$ complex occurs at acidic $\mathrm{pH}$. The extracts were added 
to tubes containing distilled water and molybdate reagent solution (Molybdate reagent: sodium phosphate $(28 \mathrm{mM})$, sulphuric acid $(0.6 \mathrm{M})$, and ammonium molybdate $4 \mathrm{mM})$. Tubes were vortexed, followed by were incubated for $90 \mathrm{~min}$ at $90^{\circ} \mathrm{C}$. Tubes were cooled to room temperature and the absorbance of the mixture was determined at $695 \mathrm{~nm}$. The results were expressed as $\mathrm{mg} \mathrm{AAE} / \mathrm{g}$ extract.

\subsubsection{DMPD radical scavenging activity}

DMPD (N,N-dimethyl- $p$-phenylendiamine) radical scavenging activity was determined by the method of Schlesier et al. [48] $100 \mathrm{mM}$ DMPD and $0.05 \mathrm{M}$ ferric chloride solutions prepared freshly and were involved with $0.1 \mathrm{M}$ acetate buffer $(\mathrm{pH}=5.25)$. The absorbance of reagent at $505 \mathrm{~nm}$ was equilibrated to $0.900 \pm 0.100$. After that, $50 \mu \mathrm{l}$ from each extract added to the reagent and absorbance of the reaction mixture was determined at $505 \mathrm{~nm}$. Ascorbic acid was used as reference.

\subsubsection{Ferric ion-chelating activity}

The metal chelating activity of all extracts was determined by the method of Chua et al. [49]. $20 \mu \mathrm{l}$ extract mixed with $2 \mathrm{mM} \mathrm{FeCl}$. Then $5 \mathrm{mM}$ ferrozine solution added to the mixture and the reaction was started. After 10 minutes passed, the absorbance of the reaction mixture was determined at $562 \mathrm{~nm}$. EDTA was used as reference. The inhibition of $\mathrm{Fe}^{+2}$-ferrozine complex establishment (\%) was determined according to this equation (Eq. 2):

$$
\text { Inhibition }(\%)=\left(\mathrm{A}_{\text {control }}-\mathrm{A}_{\text {sample }}\right) / \mathrm{A}_{\text {control }} \times 100
$$

\subsubsection{Ferric-reducing antioxidant power (FRAP)}

$2.5 \mathrm{ml}$ of potassium ferricyanide and plant extracts were added into $2.5 \mathrm{ml}$ of phosphate buffer (pH 6.6). The reaction proceeded for $20 \mathrm{~min}$ at $50{ }^{\circ} \mathrm{C}$. Then trichloroacetic acid $(10 \%), \mathrm{FeCl}_{3}(0.1 \%, \mathrm{w} / \mathrm{v})$ were added. After the $30 \mathrm{~min}$ of incubation, the absorbance of the mixture was determined at $700 \mathrm{~nm}$. Increase in absorbance of the reaction indicated ferric-reducing antioxidant power of the extracts [50].

\subsection{Total phenolic content}

Folin-Ciocalteu method [51] was used to determine the total phenolic content. The plant extract is dissolved in ethanol (75\%) as the concentration is $2 \mathrm{mg} / \mathrm{ml}$. Folin-Ciocalteau and $20 \%$ sodium carbonate solution are added to the extracts. Dilutions of gallic acid are prepared at concentrations of $50 \mathrm{mg} / \mathrm{ml}, 100$ $\mathrm{mg} / \mathrm{ml}, 150 \mathrm{mg} / \mathrm{ml}, 250 \mathrm{mg} / \mathrm{ml}$ and $500 \mathrm{mg} / \mathrm{ml}$ in order to form the calibration curve. All tubes are allowed to incubate at $40^{\circ} \mathrm{C}$ for $30 \mathrm{~min}$. At the end of the time, the absorbance is read on the spectrophotometer at 765 $\mathrm{nm}$ wavelength. According to the calibration curve prepared with the gallic acid solutions, the total phenolic concentration is calculated as the GAE using the absorbance of the sample solution Equation (Eq. 3) of the calibration graph was found as presented below:

$$
\mathrm{y}=2.4632 \mathrm{x}-0.0419 \text { and } \mathrm{r}^{2}: 0.9935
$$

\subsection{Statistical analysis}

Statistical analysis of enzyme inhibition was performed by applying oneway ANOVA, Dunnett multiple comparison test with GraphPad Prism 6.0 program. In the mean $p$ values of $p<0.05$ was considered as significant ${ }^{* * * *} p<0.001,{ }^{* *} p<0.01,{ }^{*} p<0.05$, ns $\left.p>0.05\right)$. All experiments were studied in triplicate. The mean and the standard error of the mean values $(n=3)$ were determined with the Microsoft Excel program.

Author contributions: Concept, Design - H.N.E., D.D.O., İ.E.O., N.O., M.A.; Supervision - H.N.E., D.D.O., İ.E.O.; Resource -H.N.E., D.D.O., İ.E.O., N.O., M.A.; Data Collection and/or Processing -H. N.E., D.D.O., İ.E.O.; Materials H.N.E., D.D.O., İ.E.O., N.O., M.A.; Analysis and/or Interpretation -H.N.E., D.D.O., İ.E.O., N.O., M.A.; Literature Search - H.N.E., D.D.O., İ.E.O.; Writing -H.N.E., D.D.O., İ.E.O, N.O.; Critical Reviews -H.N.E., D.D.O., İ.E.O., N.O., M.A.

Conflict of interest statement: The authors declared no conflict of interest.

\section{REFERENCES}

[1] American Diabetes Association. Diagnosis and classification of diabetes mellitus. Diabetes Care. 2014; 37 Suppl 1: 8190. [CrossRef] 
[2] Muriach M, Flores-Bellver M, Romero FJ, Barcia JM. Diabetes and the brain: oxidative stress, inflammation, and autophagy. Oxid Med Cell Longev. 2014; 2014: 102158. [CrossRef]

[3] You Q, Chen F, Wang X, Jiang YM, Lin SY. Anti-diabetic activities of phenolic compounds in muscadine against alpha-glucosidase and pancreatic lipase. LWT-Food Sci Technol. 2012; 46(1): 164-168. [CrossRef]

[4] Racette SB, Deusinger SS, Deusinger RH. Obesity: overview of prevalence, etiology, and treatment. Phys Ther. 2003; 83(3): 276-288. [CrossRef]

[5] Buchholz T, Melzig MF. Polyphenolic compounds as pancreatic lipase inhibitors. Planta Med. 2015; 81(10): 771-783. [CrossRef]

[6] Kim GN, Shin MR, Shin SH, Lee AR, Lee JY, Seo BI, Kim MY, Kim TH, Noh JS, Rhee MH, Roh SS. Study of antiobesity effect through inhibition of pancreatic lipase activity of Diospyros kaki fruit and Citrus unshiu peel. Biomed Res Int. 2016; 2016: 1723042. [CrossRef]

[7] Saedi E, Gheini MR, Faiz F, Arami MA. Diabetes mellitus and cognitive impairments. World J Diabetes. 2016; 7(17): 412-422. [CrossRef]

[8] Profenno LA, Porsteinsson AP, Faraone SV. Meta-analysis of Alzheimer's disease risk with obesity, diabetes, and related disorders. Biol Psychiatry. 2010; 67(6): 505-512. [CrossRef]

[9] Greig NH, Utsuki T, Yu Q, Zhu X, Holloway HW, Perry T, Lee B, Ingram DK, Lahiri DK. A new therapeutic target in Alzheimer's disease treatment: Attention to butyrylcholinesterase. Curr Med Res Opin. 2001; 17(3): 159-165. [CrossRef]

[10] Davis PH. Flora of Turkey and the East Aegean Islands, Edinburgh University Press, Edinburgh, 1965.

[11] Gurdal B, Kultur S. An ethnobotanical study of medicinal plants in Marmaris (Mugla, Turkey). J Ethnopharmacol. 2013; 146(1): 113-126. [CrossRef]

[12] Karaman Ö, Elgin Cebe G. Diyabet ve Türkiye' de antidiyabetik olarak kullanılan bitkiler. J Fac Pharm Ankara. 40(3): 47-61. [CrossRef]

[13] Honda G, Yeşilada E, Tabata M, Sezik E, Fujita T, Takeda Y, Takaishi Y, Tanaka T. Traditional medicine in Turkey VI. Folk medicine in West Anatolia: Afyon, Kütahya, Denizli, Muğla, Aydin provinces. J Ethnopharmacol. 1996; 53(2): 75-87. [CrossRef]

[14] Perry NS, Houghton PJ, Theobald A, Jenner P, Perry EK. In-vitro inhibition of human erythrocyte acetylcholinesterase by Salvia lavandulaefolia essential oil and constituent terpenes. J Pharm Pharmacol. 2000; 52(7): 895-902. [CrossRef]

[15] Mehran MM, Norasfard MR, Abedinzade M, Khanaki K. Lamium album or Urtica dioica? Which is more effective in decreasing serum glucose, lipid and hepatic enzymes in streptozotocin induced diabetic rats: A comparative study. Afr J Tradit Complement Altern Med. 2015; 12(5): 84-88. [CrossRef]

[16] Çam ME, Yildiz S, Ertaş B, Acar AE, Taşkın T. Antidiabetic effects of Salvia triloba and Thymus praecox subsp. skorpilii var. skorpilii in a rat model of streptozotocin/nicotinamide-induced diabetes. Marmara Pharm J. 2017; 21(4): 818-827. [CrossRef]

[17] Şenol FS, Orhan I, Celep F, Kahraman A, Doğan M, Yilmaz G, Şener B. Survey of 55 Turkish Salvia taxa for their acetylcholinesterase inhibitory and antioxidant activities. Food Chem. 2010; 120(1): 34-43. [CrossRef]

[18] Kindl M, Blažeković B, Bucar F, Vladimir-Knežević S. Antioxidant and anticholinesterase potential of six Thymus species. Evid Based Complement Alternat Med. 2015; 2015: 1-10. [CrossRef]

[19] Chung YK, Heo HJ, Kim EK, Kim HK, Huh TL, Lim Y, Kim SK, Shin DH. Inhibitory effect of ursolic acid purified from Origanum majorana L. on the acetylcholinesterase. Mol Cells. 2001; 11(2): 137-143

[20] Iauk L, Acquaviva R, Mastrojeni S, Amodeo A, Pugliese M, Ragusa M, Loizzo MR, Menichini F, Tundis R. Antibacterial, antioxidant and hypoglycaemic effects of Thymus capitatus (L.) Hoffmanns. et Link leaves' fractions. J Enzyme Inhib Med Chem. 2014; 30(3): 360-365. [CrossRef]

[21] Kabbaoui ME, Chda A, Mejrhit N, Azdad O, Farah A, Aarab L, Bencheikh R, Tazi A. Antidiabetic effect of Thymus satureioides aqueous extract in streptozotocin-induced diabetic rats. Int J Pharm Pharm Sci. 2016; 8(9): 140-145. [CrossRef]

[22] Ekoh SN, Akubugwo EI, Ude VC, Edwin N. Anti-hyperglycemic and anti-hyperlipidemic effect of spices (Thymus vulgaris, Murraya koenigii, Ocimum gratissimum and Piper guineense) in alloxan-induced diabetic rats. Int J Biosci. 2014; 4(2): 179-187. [CrossRef] 
[23] Perez Gutierrez RM Inhibition of advanced glycation end-product formation by Origanum majorana in vitro and in streptozotocin-induced diabetic rats. Evid Based Complement Alternat Med. 2012; 2012:598638. [CrossRef]

[24] Vujicic M, Nikolic I, Kontogianni VG, Saksida T, Charisiadis P, Vasic B, Stosic-Grujicic S, Gerothanassis IP, Tzakos AG, Stojanovic I. Ethyl acetate extract of Origanum vulgare L. ssp. hirtum prevents streptozotocin-induced diabetes in C57BL/ 6 mice. J Food Sci. 2016; 81(7): H1846-H1853. [CrossRef]

[25] Huang M, Wang P, Xu S, Xu W, Xu W, Chu K, Lu J. Biological activities of salvianolic acid B from Salvia miltiorrhiza on type 2 diabetes induced by high-fat diet and streptozotocin. Pharm Biol. 2015; 53(7): 1058-1065. [CrossRef]

[26] Perfumi M, Arnold N, Tacconi R. Hypoglycemic activity of Salvia fruticosa Mill. from Cyprus. J Ethnopharmacol. 1991; 34(2-3): 135-140. [CrossRef]

[27] Jimenez J, Risco S, Ruiz T, Zarzuelo A. Hypoglycemic activity of Salvia lavandulifolia. Planta Med. 1986; 52(04): 260262.

[28] Kianbakht S, Dabaghian FH. Improved glycemic control and lipid profile in hyperlipidemic type 2 diabetic patients consuming Salvia officinalis L. leaf extract: A randomized placebo. Controlled clinical trial. Complement Ther Med. 2013; 21(5): 441-446. [CrossRef]

[29] Eidi A, Eidi M. Antidiabetic effects of sage (Salvia officinalis L.) leaves in normal and streptozotocin-induced diabetic rats. Diabetes Metab Syndr: Clin Res Rev. 2009; 3(1): 40-44. [CrossRef]

[30] Vuksan V, Jenkins AL, Dias AG, Lee AS, Jovanovski E, Rogovik AL, Hanna A. Reduction in postprandial glucose excursion and prolongation of satiety: possible explanation of the long-term effects of whole grain Salba (Salvia hispanica L.). Eur J Clin Nutr. 2010; 64(4): 436-438. [CrossRef]

[31] Nickavar B, Abolhasani L. Bioactivity-guided separation of an a-amylase inhibitor flavonoid from Salvia virgata. Iran J Pharm Res. 2013; 12(1): 57-61.

[32] Khan T, Zahid M, Asim M, Shahzad ul H, Iqbal Z, Choudhary MI, Ahmad VU. Pharmacological activities of crude acetone extract and purified constituents of Salvia moorcraftiana Wall. Phytomedicine. 2002; 9(8): 749-752. [CrossRef]

[33] Flores-Bocanegra L, Gonzalez-Andrade M, Bye R, Linares E, Mata R. a-Glucosidase inhibitors from Salvia circinata. J Nat Prod. 2017; 80(5): 1584-1593. [CrossRef]

[34] Asghari B, Salehi P, Sonboli A, Nejad Ebrahimi S. Flavonoids from Salvia chloroleuca with a-amylsae and aglucosidase inhibitory effect. Iran J Pharm Res. 2015; 14(2): 609-615.

[35] Bisio A, De Mieri M, Milella L, Schito AM, Parricchi A, Russo D, Alfei S, Lapillo M, Tuccinardi T, Hamburger M, De Tommasi N. Antibacterial and hypoglycemic diterpenoids from Salvia chamaedryoides. J Nat Prod. 2017; 80(2): 503514. [CrossRef]

[36] Colombo G, Carai MM, Loi B, Zaru A, Riva A, Cabri W, Morazzoni P. Hypoglycemic effects of a standardized extract of Salvia miltiorrhiza roots in rats. Pharmacogn Mag. 2015; 11(44): S545-S549. [CrossRef]

[37] Huang M, Xie Y, Chen L, Chu K, Wu S, Lu J, Chen X, Wang Y, Lai X. Antidiabetic effect of the total polyphenolic acids fraction from Salvia miltiorrhiza bunge in diabetic rats. Phytother Res. 2012; 26(6): 944-948. [CrossRef]

[38] Cai H, Lian L, Wang YU, Yu Y, Liu WEI. Protective effects of Salvia miltiorrhiza injection against learning and memory impairments in streptozotocin-induced diabetic rats. Exp Ther Med. 2014; 8(4): 1127-1130. [CrossRef]

[39] Hasanein P, Felehgari Z, Emamjomeh A. Preventive effects of Salvia officinalis L. against learning and memory deficit induced by diabetes in rats: Possible hypoglycaemic and antioxidant mechanisms. Neurosci Lett. 2016; 622: 72-77. [CrossRef]

[40] Kleinschnitz C, Yu HY, Zhang ZL, Chen J, Pei A, Hua F, Qian X, He J, Liu CF, Xu X. Carvacrol, a food-additive, provides neuroprotection on focal cerebral ischemia/reperfusion injury in mice. PloS One. 2012; 7(3): 1-8. [CrossRef]

[41] Topçu G, Öztürk M, Kuşman M, Barla Demirkoz AA, Kolak U, Ulubelen A. Terpenoids, essential oil composition and fatty acids profile, and biological activities of Anatolian Salvia fruticosa Mill. Turk J Chem. 2013; 37: 619-632. [CrossRef]

[42] Orhan I, Kartal M, Kan Y, Sener B. Activity of essential oils and individual components against acetyl- and butyrylcholinesterase. Z Naturforsch C. 2008; 63(7-8): 547-553. [CrossRef]

[43] Ellman GL, Courtney KD, Andres V, Feather-Stone RM. A new and rapid colorimetric determination of acetylcholinesterase activity. Biochem Pharmacol. 1961; 7: 88-95. [CrossRef]

[44] Ali H, Houghton PJ, Soumyanath A. a-Amylase inhibitory activity of some Malaysian plants used to treat diabetes; with particular reference to Phyllanthus amarus. J Ethnopharmacol. 2006; 107(3): 449-455. [CrossRef] 
[45] Lam SH, Chen JM, Kang CJ, Chen CH, Lee SS. a-Glucosidase inhibitors from the seeds of Syagrus romanzoffiana. Phytochemistry. 2008; 69(5): 1173-1178. [CrossRef]

[46] Lee YM, Kim YS, Lee Y, Kim J, Sun H, Kim JH, Kim JS. Inhibitory activities of pancreatic lipase and phosphodiesterase from Korean medicinal plant extracts. Phytother Res. 2012; 26(5): 778-782. [CrossRef]

[47] Prieto P, Pineda M, Aguilar M. Spectrophotometric quantitation of antioxidant capacity through the formation of a phosphomolybdenum complex: Specific application to the determination of vitamin E. Anal Biochem. 1999; 269(2): 337-341. [CrossRef]

[48] Schlesier K, Harwat M, Bohm V, Bitsch R. Assessment of antioxidant activity by using different in vitro methods. Free Radic Res. 2002; 36(2): 177-187. [CrossRef]

[49] Chua MT, Tung YT, Chang ST. Antioxidant activities of ethanolic extracts from the twigs of Cinnamomum osmophloeum. Bioresour Technol. 2008; 99(6): 1918-1925. [CrossRef]

[50] Oyaizu M. Studies on products of browning reaction. Jpn J Nutr Diet. 1986; 44(6): 307-315. [CrossRef]

[51] Singleton VL, Rossi JA. Colorimetry of total phenolics with phosphomolybdic-phosphotungstic acid reagents. Am J Enol Vitic. 1965; 16(3): 144-158.

This is an open access article which is publicly available on our journal's website under Institutional Repository at http://dspace.marmara.edu.tr. 